\title{
The Relationship between Pollen Viability and Filled Grains in Native Indonesian Rice Cultivars under High Temperature at Flowering Stage
}

\author{
Sabaruddin Zakaria, Edwar Rustam¹, Bakhtiar Basyah, Trisda Kurniawan
}

10.18805/IJARe.AF-684

\begin{abstract}
Background: The research was conducted to screen rice cultivars with resistance ability to high-temperature conditions and analyze the relationship between pollen viability and filled grain of native Indonesia rice cultivars.

Methods: The rice seeds were germinated, sown into a tray and then transplanted into pots filled with sandy loam and compost 3:1. After $20 \%$ of flowering, four pots of each cultivar were kept under ambient temperature $\left(28-32^{\circ} \mathrm{C}\right)$ and the other four pots were transferred to high-temperature $\left(33-38^{\circ} \mathrm{C}\right)$ conditions. Pollen stainability and pollen germination were conducted using IKI solution and by germinating them under in vitro conditions respectively before being viewed under the light microscope. Yield characters were analyzed to obtain a relationship with pollen viability.

Result: Percentage of pollen germination, filled and empty grains of rice cultivars significantly differed between the two conditions by t-test. Ciherang and Sigeudop were two resistant cultivars for high-temperature treatment, with filled grain percentage more than $85 \%$. There was a strong relationship between pollen germination and filled grains at ambient temperature $(r=0.95 ; p<0.01)$ and high temperature $(r=0.94 ; p<0.01)$. Rice cultivars that show high pollen germination under high-temperature conditions would produce a high percentage of filled grains.
\end{abstract}

Key words: Ambient temperature, Filled grain, High temperature, Pollen viability, Rice cultivars.

\section{INTRODUCTION}

Rice is the most important crop and the primary source of calories for approximately half of the world's human population and more than $80 \%$ in Asian countries, particularly Indonesia. Rice is a major cereal grown in an irrigated agricultural field of South and Southeast Asia, with maximum day temperature either close to or higher than the top critical temperature threshold ranging between $33^{\circ} \mathrm{C}$ (Nakagawa et al., 2003) and $35^{\circ} \mathrm{C}$ (Kumar et al., 2015). Hightemperature stress is defined as the rise in temperature beyond a critical threshold for an amount of time sufficient to cause irreversible damage to plant growth and development (Karwa et al., 2020).

Rice responses to high temperature differ according to the developmental stage, with the highest sensitivity recorded at the reproductive stage, starting from anthesis to grain filling, which dictates plant reproduction (Senguttuvel et al., 2020). Temperature more than $35^{\circ} \mathrm{C}$ at anthesis and lasting for more than one hour can lead to high sterility in rice (Jagadish 2020). High-temperature stress that caused an increase in spikelet sterility was attributed to impaired pollination (Matsui et al. 2005) and pollen germination (Jagadish et al. 2010), as well as accumulation of flavonoids in microspore (Paupière et al. 2017).

Within a floret, anther and pollen are more sensitive to high temperature than ovules and floret sterility at a temperature more than $30^{\circ} \mathrm{C}$ has been correlated with diminished anther dehiscence (Kobayashi et al. 2011), production of fewer pollen grains (Harsant et al. 2013) and
Department of Agrotechnology, Faculty of Agriculture, Syiah Kuala University, JI. Tgk. Syech Abdurrauf No. 8, Darussalam-Banda Aceh, Indonesia.

${ }^{1}$ Agricultural Agency, South Aceh District, Aceh Province, Indonesia.

Corresponding Authors: Sabaruddin Zakaria and Trisda Kurniawan, Department of Agrotechnology, Faculty of Agriculture, Syiah Kuala University, JI. Tgk. Syech Abdurrauf No. 8, Darussalam-Banda Aceh, Indonesia.

Email: zaksabar@unsyiah.ac.id; trisdakurniawan@unsyiah.ac.id

How to cite this article: Zakaria, S., Rustam, E., Basyah, B. and Kurniawan, T. (2022). The Relationship between Pollen Viability and Filled Grains in Native Indonesian Rice Cultivars under High Temperature at Flowering Stage. Indian Journal of Agricultural Research. DOI: 10.18805/IJARe.AF-684.

Submitted: 16-08-2021 Accepted: 22-01-2022 Online: 14-02-2022

reduced in vivo pollen germination (Farooq et al., 2011). In anthers with poor dehiscence that have been damaged by exposure to high temperatures at the flowering stage, a decrease in pollen volume, pollen size and starch accumulation in pollen grains has been reported (Kumar et al., 2015). The study also revealed that high temperature increased the pollen sterility and unable to germinate on stigma, thus increasing the spikelet sterility that led to decreased productivity in selected rice genotypes (Hilali et al., 2019). These results indicate that periods of high temperature negatively affected sexual reproduction, such that even high pollen production may not result in successful 
The Relationship between Pollen Viability and Filled Grains in Native Indonesian Rice Cultivars under High Temperature...

fertilization due to low germination (Flores-Rentería et al., 2018).

Increasing daytime temperature results in decreasing pollen grain numbers per anther (Yang et al., 2017). Pollen grain abortion showed similar trends and abortion was virtually complete at $36^{\circ} \mathrm{C}$ (Sakata et al., 2000). Pollen development at $36^{\circ} \mathrm{C}$ ceased almost exclusively at the uninucleate stage, corresponding to the mean final length of the anthers. Aborting pollen was swollen and misshapen (Harsant et al., 2013). Rice yield per acre is determined by the number of productive tiller per unit area, fertile spikelets per panicle and grain weight (Prasad et al., 2006), which is very sensitive to high temperature (Sabaruddin et al., 2002).

The unfavorable high temperature on cereal crop yield results from the negative impact on the development of morphological units that contribute to harvest index and its responses various with the timing, duration and severity of the heat stress (Aochen and Prakash, 2015; Barnabás et al., 2008). Despite the importance of the negative effect of high temperature on cereal crop yield, detailed analysis that caused a reduction in yield at high temperature was not fully elucidated.

Indonesia is a tropical country where the maximum temperature can reach more than $35^{\circ} \mathrm{C}$, especially during the dry season. This condition significantly affects the productivity of rice plants in the country. In general, rice cultivated in Indonesia belongs to Javanica and Indica ecotypes. This study hopes that the mechanism for reducing rice yields at high-temperature conditions for Indica or Javanica could be elucidated. Here we examine the relationship between pollen viability and filled grains of native Indonesia rice cultivars under different temperature conditions at the flowering stage. We also investigate the morphological characteristics of pollen in susceptible and resistant rice cultivars belong to Indica and Javanica rice ecotype under high-temperature conditions.

\section{MATERIALS AND METHODS}

\section{Plant cultivation and management}

The research was conducted from January to September 2017 in the experimental farm of the Agriculture Faculty, Syiah Kuala University, Aceh Province, Indonesia. Thirteen cultivars of native Indonesian rice (Indica ecotype) from Aceh Province consist of Rangan Lango, Bo Santet Simantok, Sigeudop, Sigodok, Sigupai, Jamai Asan, Semere, Sikuneng, Bo Sireutoh, Pade Malaysia, Pade Pangku, Meuligai, Sipulo and one national variety Ciherang (Javanica ecotype) were used in this research.

The rice seeds were germinated and sown into a tray containing natural sandy loam soil with $20 \%$ compost. Seedlings then were transplanted into pots filled with $5 \mathrm{~kg}$ of soil containing $3: 1(\mathrm{v} / \mathrm{v})$ of sandy loam and compost after 20 days of sowing. For the basal dressing, fertilizers were applied with $3 \mathrm{~g}$ of Urea and $2 \mathrm{~g}$ of NPK (15-15-15) per pot one day before transplanting. The top dressing was applied at 30 and 55 days after transplanting using only urea with a rate of $3 \mathrm{~g}$ per pot. All of the plants were growing at ambient temperature until the early flowering stage.

\section{Temperatures treatment}

When the plants reached 20 per cent of flowering, four pots of each cultivar were kept under ambient temperature (28$32^{\circ} \mathrm{C}$ ), whereas four more pots were transferred to hightemperature conditions $\left(33-38^{\circ} \mathrm{C}\right)$ for five days. The panicles that emerged after five days of treatment under hightemperature conditions were tagged and used as samples for pollen stainability, pollen germination and yield character analysis. The plants transferred to the high-temperature condition were then grown again under ambient temperature until the harvesting stage.

\section{Analysis for pollen stainability and pollen germination}

The analysis of pollen stainability was conducted by fixating released pollen from the anthers in $70 \%(\mathrm{v} / \mathrm{v})$ ethanol when pollination occurred. For pollen analysis under hightemperature conditions, the samples were taken from the panicle that emerged after five days of treatment. Then, the pollens were dyed by using a solution containing $0.18 \%(\mathrm{w} / \mathrm{v})$ iodine and $1 \%(\mathrm{w} / \mathrm{v})$ potassium iodide (IKI solution). Pollens that showed dark green color were judged as fertile. About 200-300 pollens per spikelet were analyzed and the status of pollen's fertility was determined. Average four spikelets were used to analyze the status of pollens fertility for each cultivar of rice plant. Analysis of pollen germination was conducted by germinating them under in vitro conditions. The pollens were released from the anther and put in a germination medium ( $1 \% \mathrm{w} / \mathrm{v}$ agar, $20 \% \mathrm{w} / \mathrm{v}$ sucrose and $20 \mathrm{ppm} w / \mathrm{v}$ boric acid) in a Petridis. Then, the pollens were incubated at a temperature of $20^{\circ} \mathrm{C}$ for $30-40$ minutes. About 200-300 pollens released from four panicles of every cultivar were observed under the light microscope.

\section{Yield characters analysis}

The variables used for yield characters analysis were the percentage of filled and empty grain, grains number per panicle, panicle length, the weight of 1000 grains and time needed for $5 \%$ flowering. Correlation analysis was performed based on data for pollen stainability and pollen germination with the filled grains.

\section{RESULTS AND DISCUSSION \\ Effect of temperature on pollen viability}

The percentage of pollen stainability, pollen germination, filled and empty grains of rice cultivars under ambient and hightemperature conditions are shown in Table 1. Percentage of pollen stainability had a significant difference in some cultivars and nonsignificant difference in others by t-test.

The data showed that cv. Bo Santet Seumantok, Bo Sireutoh, Pade Malaysia and Pade Pangku had a high significant difference and cv. Sigeudop, Sikuneng, Sipulo and Ciherang significantly differed in pollen stainability 
The Relationship between Pollen Viability and Filled Grains in Native Indonesian Rice Cultivars under High Temperature...

between ambient temperature and high temperature. Whereas cv. Rangan Lango, Sigodok, Sigupai, Jamai asan, Semere, Meuligai, USK 1 and Semerie did not significantly differ in pollen stainability between the two conditions. Under the high-temperature condition, cv. Ciherang had the highest percentage of pollen stainability, whereas cv. Bo Santet Simantok had the lowest. Pollen stainability of cv. Ciherang and Bo Santet Semantok under high-temperature conditions were $93.8 \%$ and $70.3 \%$, respectively.

This result was also confirmed by the light microscope photograph (Fig 1a and 1b). Almost all of the pollens in $\mathrm{cv}$. Ciherang showed a dark stain by IKI solution (Fig 1a), whereas in cv. Bo Santet Seumantok, the pollens appear transparent or unstained (Fig 1b; arrow).

Table 1 also showed that the percentage of pollen germination, filled and empty grains of rice cultivars, significantly differed between ambient temperature and hightemperature conditions. Cv. Rangan Lango and Ciherang were two cultivars that showed pollen germination reached more than $70 \%$ under ambient temperature conditions and had pollen germination reached 58.1 and $62.4 \%$, respectively, under high-temperature conditions. Whereas cv. Bo Santet Seumantok had only $29.2 \%$ and $17.8 \%$ pollen germination under ambient and high temperature, respectively. The results were also confirmed by the light microscope (Fig 1c and d). Most of the pollens in $\mathrm{cv}$. Ciherang germinated well in the germination medium in which the pollen tube appeared like a thread (Fig 1c; arrow). Whereas in cv. Bo Santet Seumantok, very few of its pollens germinated and showed like this thread.

Our data showed that the excellent viability of pollens shown by pollen stainability and germination determined filled grains of rice. The cultivars that had the ability of their pollens to germinate under high-temperature conditions also could produce high production in this extreme condition. These cultivars are thought to have the ability to increase the percentage of sufficiently pollinated florets under a hightemperature condition and thus increase the hightemperature tolerance of the pollination. The higher the germination rate of pollen, it will cause the higher the seeds are filled (Rang et al., 2011).

Cv. Rangan Lango, Sigeudop and Ciherang were more resistant to high-temperature treatment than other cultivars. A high percentage of filled grain shows it under the hightemperature condition that reached $83.5-88.6 \%$. The percentage of filled grains in these cultivars under ambient temperature was $90.3-93.8 \%$ and the percentage of empty grains ranged from $11.4-16.5 \%$ under high-temperature conditions. This data also confirmed a significant relationship between the percentage of pollen germination and filled grains at ambient temperature and high temperature. This is indicated by the correlation at the ambient temperature with a value of $r=0.948 ; p<0.01$ (Fig 2 ) and high temperatures with a value of $r=0.950 p<0.01$ (Fig 3). This correlation indicates that a high percentage of pollen germination will determine a high percentage of filled grains. The data showed a positive correlation between the seeds filled and the germination of pollen. Sequentially germination of pollen increased in filled seeds at high-temperature conditions.

The internal and external factors could limit pollen production, viability and germinability rates, that cause the decreasing in seed formation or yield (Shivanna et al., 1991). Therefore, high pollen quantity and quality profile are central

Table 1: Percentage of pollen stainability, pollen germination, filled grains and empty grains of rice cultivars under ambient and high temperature condition.

\begin{tabular}{|c|c|c|c|c|c|c|c|c|c|c|c|c|}
\hline \multirow[t]{2}{*}{ Cultivars } & \multicolumn{3}{|c|}{$\begin{array}{c}\text { Percentage of pollen } \\
\text { stainability }\end{array}$} & \multicolumn{3}{|c|}{$\begin{array}{c}\text { Percentage of pollen } \\
\text { germination }\end{array}$} & \multicolumn{3}{|c|}{$\begin{array}{l}\text { Percentage of filled } \\
\text { grains }(\%)\end{array}$} & \multicolumn{3}{|c|}{$\begin{array}{l}\text { Percentage of empty } \\
\text { grains (\%) }\end{array}$} \\
\hline & AT & HT & & AT & HT & & AT & $\mathrm{HT}$ & & AT & $\mathrm{HT}$ & \\
\hline Rangan Lango & 94,8 & 90,7 & ns & 70,2 & 58,1 & ** & 90,3 & 83,5 & $* *$ & 9,7 & 16,5 & ** \\
\hline Bo Santet Simantok & 84,1 & 70,3 & ** & 29,2 & 17,8 & ** & 54,7 & 30,4 & ** & 45,3 & 69,6 & ** \\
\hline Sigeudop & 94,8 & 91,1 & * & 67,3 & 56,6 & * & 90,4 & 85,7 & $* *$ & 9,6 & 14,3 & $* *$ \\
\hline Sigodok & 89,7 & 88,5 & ns & 59,0 & 34,5 & ** & 78,8 & 47,9 & $* *$ & 21,2 & 52,1 & $* *$ \\
\hline Sigupai & 90,6 & 86,8 & ns & 54,4 & 41,4 & ** & 76,9 & 63,3 & $* *$ & 23,1 & 36,7 & $* *$ \\
\hline Jamai Asan & 94,2 & 90,0 & ns & 54,7 & 31,9 & ** & 76,7 & 55,8 & $* *$ & 23,3 & 44,2 & $* *$ \\
\hline Semere & 95,0 & 91,6 & ns & 61,8 & 45,4 & ** & 82,3 & 72,0 & $* *$ & 17,7 & 28,0 & $* *$ \\
\hline Sikuneng & 95,1 & 91,1 & * & 64,8 & 50,8 & ** & 88,5 & 81,2 & $* *$ & 11,5 & 18,8 & $* *$ \\
\hline Bo Sireutoh & 91,9 & 78,0 & $* *$ & 50,3 & 27,9 & ** & 72,1 & 52,0 & $* *$ & 27,9 & 48,0 & $* *$ \\
\hline Pade Malaysia & 91,6 & 81,0 & $* *$ & 48,7 & 20,1 & ** & 81,6 & 43,3 & $* *$ & 18,4 & 56,7 & $* *$ \\
\hline Pade Pangku & 96,4 & 86,8 & $* *$ & 55,2 & 28,4 & ** & 79,1 & 55,4 & $* *$ & 20,9 & 44,6 & $* *$ \\
\hline Meuligai & 93,4 & 90,6 & $\mathrm{~ns}$ & 52,2 & 39,5 & ** & 79,8 & 54,9 & $* *$ & 20,2 & 45,1 & $* *$ \\
\hline Sipulo & 93,1 & 87,3 & * & 51,2 & 39,3 & ** & 77,7 & 51,0 & $* *$ & 22,3 & 49,0 & $* *$ \\
\hline Ciherang & 97,5 & 93,8 & * & 70,4 & 62,4 & ** & 93,8 & 88,6 & $* *$ & 6,2 & 11,4 & $* *$ \\
\hline
\end{tabular}

AT: Ambient temperature $\left(28-32^{\circ} \mathrm{C}\right)$, $\mathrm{HT}$ : High temperature $\left(33-38^{\circ} \mathrm{C}\right)$.

ns, * ${ }^{* *}$ : non significant and highly significant difference respectively between AT and HT by T-test (5 and $\left.1 \%\right)$. 


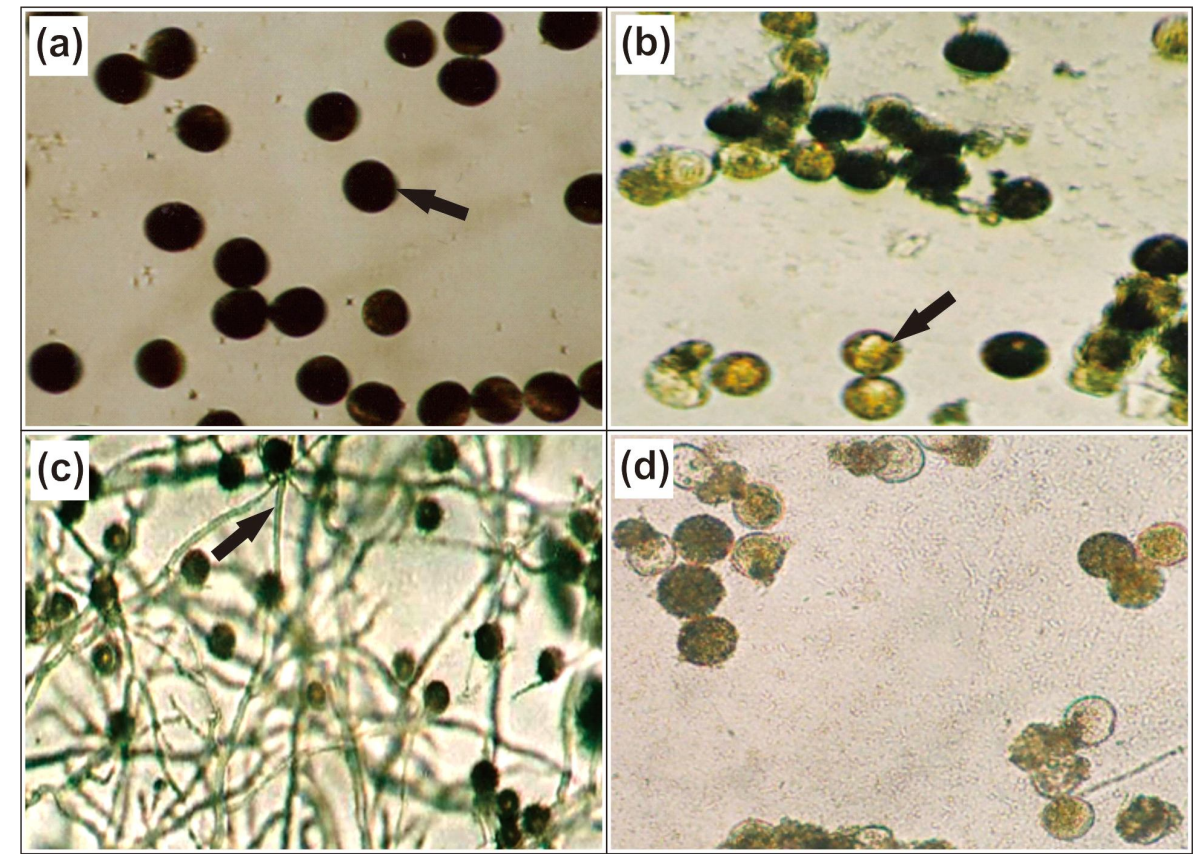

Fig 1: Show morphology of pollen in cv. Ciherang and Bo Santet Seumantok under high temperature condition. Most pollens of cv. Ciherang stained clearly by IKI solution (Fig 1 a; arrow), whereas most pollen of cv. Bo Santet Seumantok showed transparent or

unstained by IKI solution (Fig $1 \mathrm{~b}$; arrow). Most of pollens in cv. Ciherang showed good germination with thread like pollen tube growth under high temperature conditions (Fig $1 \mathrm{c}$; arrow) and there were no pollens germinated under high temperature conditions in cv. Bo Santet Seumantok (Fig $1 \mathrm{c}$ ).

to viable seed formation and propagation. This research confirmed that pollen stainability, pollen germination and grain set percentage differ among cultivars to high temperatures during anthesis. High pollen stainability and pollen germination in cv. Rangan Lango, Sigeudop and Ciherang showed that these cultivars were more tolerant to high-temperature stress than other cultivars.

Pollen fertility are essential for understanding the plant's reproduction problem, both in rice (graminae) and in leguminoceae such as lentil (Baidya et al., 2021) and chickpea (Kiran et al., 2016). Pollen production and pollen viability vary to a slight increase in temperature above the optimum (Fahad et al., 2018). High temperatures usually caused a lack of water in which eventually reduces the amount of quality pollen. This condition will affect the production of seeds on the panicle (Müller and Rieu, 2016; Sabaruddin et al., 2002). Within a floret, anthers and pollen are more sensitive to high temperature than ovules and floret sterility at a temperature more than $30^{\circ} \mathrm{C}$ has been correlated with increasing pollen sterility (Paupière et al., 2017).

The low percentage of filled grains in sensitive cultivars as Bo Santet Seumantok to high-temperature conditions was caused by the limitation of pollens germination, which eventually caused the decrease in egg cells' fertilization. It has been reported that high ambient temperatures can damage the process of grain filling in rice, potentially inducing the endosperm to become chalky (Luo et al., 2018). Therefore, rising in temperature leads to a decrease in rice yield (Wang et al. 2020).

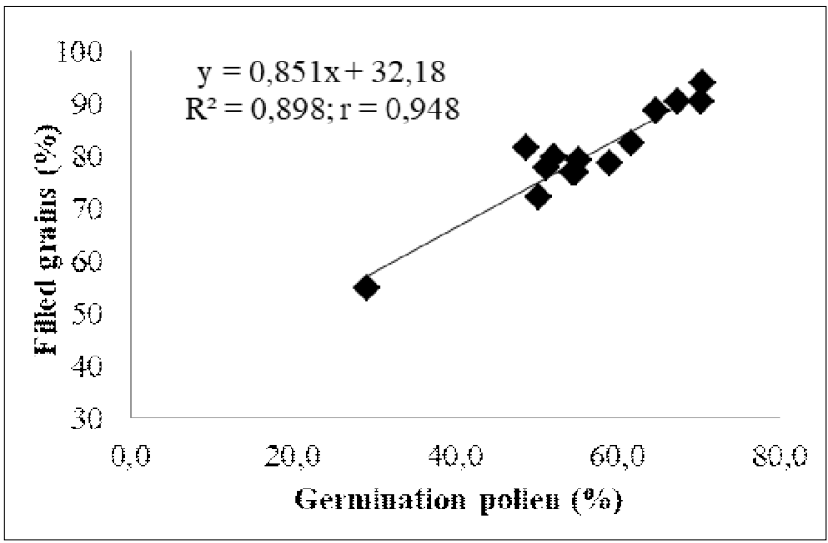

Fig 2: Correlation between the percentage of pollen germination with the percentage of filled grains under ambient temperature $\left(28-32^{\circ} \mathrm{C}\right)$.

\section{Effect of temperature on other agronomic characters}

Table 2 showed grain numbers per panicle, panicle length, the weight of 1000 grains and the time needed for $5 \%$ of flowering. Temperature treatment did not significantly differ on all of these variables (data is not shown). The table showed that cv. Sikuneng and Bo Santet Seumantok had the most significant dan the lowest grain number per panicle, respectively. The grain number of $\mathrm{cv}$. Sikuneng and cv. Bo Santet Seumantok were 205 and 93.8 grains, respectively. Table 2 also showed that all of these cultivars had a panicle 
The Relationship between Pollen Viability and Filled Grains in Native Indonesian Rice Cultivars under High Temperature...

Table 2: Grain numbers per panicle, panicle length, 1000 grains weight and time for 5 per cent of flowering peach cultivars.

\begin{tabular}{|c|c|c|c|c|c|c|c|}
\hline \multirow[t]{2}{*}{ Cultivars } & \multicolumn{2}{|c|}{$\begin{array}{c}\text { Grain number } \\
\text { per panicle }\end{array}$} & \multicolumn{2}{|c|}{$\begin{array}{l}\text { Panicle length } \\
\text { (cm) }\end{array}$} & \multicolumn{2}{|c|}{$\begin{array}{c}\text { Weigh of } 1000 \\
\text { grains }(\mathrm{g})\end{array}$} & \multirow{2}{*}{$\begin{array}{c}\begin{array}{c}\text { Time for } 5 \% \\
\text { flowering }\end{array} \\
\text { (days) }\end{array}$} \\
\hline & & $\mathrm{Sd}$ & $(\mathrm{cm})$ & $\mathrm{Sd}$ & $(\mathrm{g})$ & $\mathrm{Sd}$ & \\
\hline Rangan Lango & 148,8 & 17,8 & 26,1 & 2,6 & 32,0 & 0,1 & 88,0 \\
\hline Bo Santet Simantok & 93,8 & 13,3 & 23,3 & 1,5 & 21,3 & 0,2 & 82,0 \\
\hline Sigeudop & 161,3 & 11,2 & 25,0 & 1,9 & 25,6 & 0,2 & 88,0 \\
\hline Sigodok & 139,1 & 24,2 & 23,2 & 2,5 & 22,0 & 0,3 & 96,0 \\
\hline Sigupai & 163,8 & 26,0 & 22,5 & 3,3 & 19,6 & 0,1 & 95,0 \\
\hline Jamai Asan & 119,0 & 8,0 & 20,9 & 1,4 & 25,1 & 0,5 & 90,0 \\
\hline Semere & 163,0 & 35,2 & 24,0 & 2,1 & 15,1 & 0,4 & 102,0 \\
\hline Sikuneng & 205,5 & 24,2 & 26,1 & 0,8 & 27,6 & 0,5 & 90,0 \\
\hline Bo Sireutoh & 142,8 & 55,1 & 23,6 & 3,3 & 18,3 & 0,3 & 74,0 \\
\hline Pade Malaysia & 138,3 & 25,1 & 21,0 & 2,2 & 18,2 & 0,1 & 79,0 \\
\hline Pade Pangku & 131,5 & 10,7 & 24,0 & 1,2 & 27,0 & 0,5 & 83,0 \\
\hline Meuligai & 153,1 & 19,3 & 24,7 & 1,6 & 23,6 & 0,5 & 118,0 \\
\hline Sipulo & 116,8 & 16,6 & 22,0 & 1,6 & 25,9 & 0,3 & 104,0 \\
\hline Ciherang & 154,5 & 27,2 & 24,9 & 1,6 & 27,6 & 0,4 & 56,0 \\
\hline
\end{tabular}

Sd- Standard deviation.

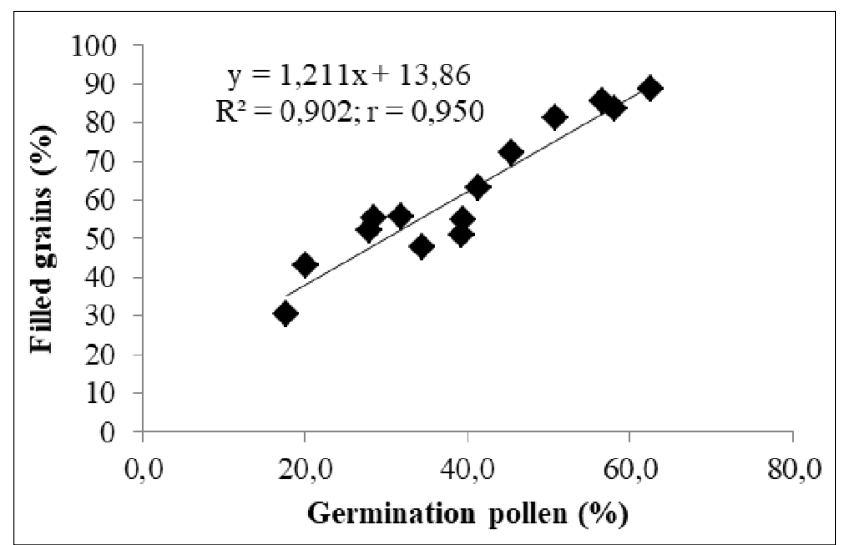

Fig 3: Correlation between the percentage of pollen germination with the percentage of filled grains under high temperature $\left(33-38^{\circ} \mathrm{C}\right)$.

length range from $20.9-26.1 \mathrm{~cm}$ with a weight of 1000 grains from $15.1-32 \mathrm{~g}$. The time needed for $5 \%$ flowering ranges from 56 days for cv. Ciherang to 118 days for cv. Meuligai. There was no difference in the number of panicles and panicle length due to temperature treatment; this was because the number of panicles and their length had been formed perfectly when the temperature treatment was carried out at $20 \%$ of flowering. Panicle size or spikelets per panicle are determined in the reproductive growth stage. Spikelet size or weight is determined during the spikelet filling growth stage Htwe et al. (2021).

\section{CONCLUSION}

There is a strong relationship between pollen germination percentage and filled grains at ambient temperature and high temperature. The higher the pollen viability was, resulting in the higher filled grain. Ciherang and Sigeudop were two resistant cultivars for high-temperature treatment, showed the percentage of filled grain under hightemperature conditions more than $85 \%$.

Conflict of interest: None.

\section{REFERENCES}

Aochen, C. and Prakash, P. (2015). Evaluation of cellular thermotolerance and associated heat tolerance in wheat (Triticum aestivum L.) under late sown condition. Indian Journal of Agricultural Research. 49(6). https://doi.org/ 10.18805/ijare.v49i6.6679.

Baidya, A., Pal, A.K., Ali, M.A. and Nath, R. (2021). High-temperature stress and the fate of pollen germination and yield in lentil (Lens culinaris Medikus). Indian Journal of Agricultural Research. 55(2). https://doi.org/10.18805/IJARe.A-5440.

Barnabás, B., Jäger, K., Fehér, A., (2008). The effect of drought and heat stress on reproductive processes in cereals. Plant, Cell Environ. 31. https://doi.org/10.1111/j.13653040.2007.01727.x

Fahad, S., Ihsan, M. Z., Khaliq, A., Daur, I., Saud, S., Alzamanan, S., Nasim, W., Abdullah, M., Khan, I.A., Wu, C., Wang, D. and Huang, J. (2018). Consequences of high temperature under changing climate optima for rice pollen characteristicsconcepts and perspectives. Archives of Agronomy and Soil Science. 64(11). https://doi.org/10.1080/03650340. 2018.1443213.

Farooq, M., Bramley, H., Palta, J.A., and Siddique, K.H.M. (2011). Heat stress in wheat during reproductive and grain-filling phases. Critical Reviews in Plant Sciences 30(6). https:/ /doi.org/10.1080/07352689.2011.615687.

Flores-Rentería, L., Whipple, A.V., Benally, G.J., Patterson, A., Canyon, B. and Gehring, C.A. (2018). Higher temperature at lower elevation sites fails to promote acclimation or adaptation to heat stress during pollen germination. Frontiers in Plant Science. 9. https://doi.org/10.3389/ fpls.2018.00536. 
The Relationship between Pollen Viability and Filled Grains in Native Indonesian Rice Cultivars under High Temperature...

Harsant, J., Pavlovic, L., Chiu, G., Sultmanis, S. and Sage, T.L. (2013). High temperature stress and its effect on pollen development and morphological components of harvest index in the C3 model grass Brachypodium distachyon. Journal of Experimental Botany. 64(10). https://doi.org/ 10.1093/jxb/ert142.

Hilali, H.S., Thind, S. and Manghat, G. (2019). Variability in high temperature induced pollen and spikelet sterility to affect productivity of rice (Oryza sativa L.) genotypes. ORYZAAn International Journal on Rice. 56(1). https://doi.org/ 10.5958/2249-5266.2019.00007.9

Htwe, T., Techato, K., Chotikarn, P. and Sinutok, S. (2021). Grain yield and environmental impacts of alternative rice (Oryza sativa L.) establishment methods in Myanmar. Applied Ecology and Environmental Research. 19(1): 507-524. https://doi.org/10.15666/AEER/1901_507524.

Jagadish, S.V.K. (2020). Heat stress during flowering in cerealsEffects and adaptation strategies. New Phytologist. 226(6). https://doi.org/10.1111/nph.16429.

Jagadish, S.V.K., Raveendran, M., Oane, R., Wheeler, T.R., Heuer, S., Bennett, J. and Craufurd, P.Q. (2010). Physiological and proteomic approaches to address heat tolerance during anthesis in rice (Oryza sativa L.). Journal of Experimental Botany. 61(1). https://doi.org/10.1093/jxb/ erp289.

Karwa, S., Bahuguna, R.N., Chaturvedi, A.K., Maurya, S., Arya, S.S., Chinnusamy, V. and Pal, M. (2020). Phenotyping and characterization of heat stress tolerance at reproductive stage in rice (Oryza sativa L.). Acta Physiologiae Plantarum. 42(2). https://doi.org/10.1007/s11738-020-3016-5.

Kiran, B.A., Venkatesh Dore, M. and Megha, B.R. (2016). Relationship of flowering pattern and pollen sterility on productivity of chickpea genotypes under temperature regimes. Indian Journal of Agricultural Research.50(6). https://doi.org/ 10.18805/ijare.v50i6.6669.

Kobayashi, K., Matsui, T., Murata, Y. and Yamamoto, M. (2011). Percentage of dehisced thecae and length of dehiscence control pollination stability of rice cultivars at high temperatures. Plant Production Science. 14(2): 89-95. https://doi.org/10.1626/pps.14.89

Kumar, N., Kumar, N., Shukla, A., Shankhdhar, S.C. and Shankhdhar, D. (2015). Impact of terminal heat stress on pollen viability and yield attributes of rice (Oryza sativa L.). Cereal Research Communications. 43(4). https://doi.org/ 10.1556/0806.43.2015.023.

Luo, R., Cao, R., Jiao, G., Lv, Y., Zhong, M., Tang, S., Wei, X. and $\mathrm{Hu}, \mathrm{P}$. (2018). The involvement of long non-coding RNAs in the formation of high temperature-induced grain chalkiness in rice. Plant Growth Regulation. 86(2). https:/ /doi.org/10.1007/s10725-018-0426-0.

Matsui, T., Kobayasi, K., Kagata, H. and Horie, T. (2005). Correlation between viability of pollination and length of basal dehiscence of the theca in rice under a hot-and-humid condition. Plant Production Science. 8(2). https://doi.org/ 10.1626/pps.8.109.
Müller, F. and Rieu, I. (2016). Acclimation to high temperature during pollen development. Plant Reproduction. 29(1-2). https:/ /doi.org/10.1007/s00497-016-0282-x.

Nakagawa, H., Horie, T., and Matsui, T. (2003). Effects of climate change on rice production and adaptive technologies. In Rice Science: Innovations and Impact for Livelihood.

Paupière, M.J., Müller, F., Li, H., Rieu, I., Tikunov, Y.M., Visser, R.G.F. and Bovy, A.G. (2017). Untargeted metabolomic analysis of tomato pollen development and heat stress response. Plant Reproduction. 30(2). https://doi.org/ 10.1007/s00497-017-0301-6.

Prasad, P.V.V., Boote, K.J. and Allen, L.H. (2006). Adverse high temperature effects on pollen viability, seed-set, seed yield and harvest index of grain-sorghum [Sorghum bicolor (L.) Moench] are more severe at elevated carbon dioxide due to higher tissue temperatures. Agricultural and Forest Meteorology. 139(3-4). https://doi.org/ 10.1016/j.agrformet.2006.07.003.

Rang, Z.W., Jagadish, S.V.K., Zhou, Q.M., Craufurd, P.Q. and Heuer, S. (2011). Effect of high temperature and water stress on pollen germination and spikelet fertility in rice. Environmental and Experimental Botany. 70(1). https:// doi.org/10.1016/j.envexpbot.2010.08.009.

Sabaruddin, Z., Toshiaki, M., Shingo, T. and Youji, N. (2002). Effect of high temperature at ripening stage on the reserve accumulation in seed in some rice cultivars. Plant Production Science. 5(2). https://doi.org/10.1626/pps.5.160.

Sakata, T., Takahashi, H., Nishiyama, I. and Higashitani, A. (2000). Effects of high temperature on the development of pollen mother cells and microspores in Barley Hordeum vulgare L. Journal of Plant Research. 113(4). https://doi.org/ 10.1007/pl00013947

Senguttuvel, P., Jaldhani, V., Raju, N.S., Balakrishnan, D., Beulah, P., Bhadhana, V.P., Mangrauthia, S.K., Neeraja, C.N., Subrahmanyam, D., Rao, P.R., Hariprasad, A.S. and Voleti, S.R. (2020). Breeding rice for heat tolerance and climate change scenario; possibilities and way forward. A review. Archives of Agronomy and Soil Science. https:/ /doi.org/10.1080/03650340.2020.1826041.

Shivanna, K.R., Linskens, H.F. and Cresti, M. (1991). Pollen viability and pollen vigor. Theoretical and Applied Genetics. 81(1). https://doi.org/10.1007/BF00226109.

Wang, W., Cai, C., He, J., Gu, J., Zhu, G., Zhang, W., Zhu, J. and Liu, G. (2020). Yield, dry matter distribution and photosynthetic characteristics of rice under elevated $\mathrm{CO}_{2}$ and increased temperature conditions. Field Crops Research. 248. https://doi.org/10.1016/j.fcr.2019.107605.

Yang, Z., Zhang, Z., Zhang, T., Fahad, S., Cui, K., Nie, L., Peng, S. and Huang, J. (2017). The effect of season-long temperature increases on rice cultivars grown in the central and southern regions of China. Frontiers in Plant Science. 8. https://doi.org/10.3389/fpls.2017.01908. 